\title{
EVALUATION OF ARTHRODESIS AND CERVICAL ALIGNMENT IN THE SURGICAL RESULTS OF CERVICAL DISCECTOMY USING POLYMETHYLMETACRYLATE
}

\author{
Marcelo Luis Mudo', Andrea Vieira Amantea', Andrei Fernandes Joaquim², \\ Mirto Nelso Prandini ${ }^{1,3}$, Sérgio Cavalheiro ${ }^{1,3}$
}

\begin{abstract}
Background and objectives: Surgical treatment of cervical radiculopathy with or without myelopathy is a controversy issue, although anterior discectomy is the most common form of treatment. Method: We present the evaluation of the arthrodesis' rate and cervical alignment in 48 patients with cervical degenerative disease (CDD) submitted to anterior cervical discectomy with interposition of polymethylmetacrylate (PMMA). Odom and Nürick scales were used to evaluation of functional status before and after surgery. Cervical spine $\mathrm{X}$-rays were used to access arthrodesis and alignment, at least 2 years after the procedure. Results: Excellent and good results (Odom I and II) were obtained in $91 \%$ of the patients with radiculopathy and in $69 \%$ of those with myelopathy. Using the chi square test of independence ( $1 \%$ of significance), there was no association between excellent and good clinical results with the presence of arthrodesis verified in cervical X-rays. The presence of cervical alignment had association with good results, whereas the misalignment was associated with unfavorable outcomes. Two patients died: one cervical hematoma and other from graft migration with cord compression. Conclusions: Cervical alignment was more important than fusion to achieve good surgical results in CDD.
\end{abstract}

KEY WORDS: discectomy, polymethylmetacrilate (PMMA), arthrodesis, fusion, cervical alignment.

\begin{abstract}
Avaliação da artrodese e do alinhamento cervical após discectomia cervical com interposição de polimetilmetacrilato

Resumo - Tema e objetivo: $O$ tratamento cirúrgico da radiculopatia cervical com ou sem mielopatia é um tema controverso, embora a discectomia por via anterior seja uma das formas mais comuns de tratamento. Método: Apresentamos a avaliação da artrodese cervical e do alinhamento pós operatório em 48 pacientes com doença degenerativa cervical (DDC) submetidos a discectomia por via anterior seguida da interposição de polimetilmetacrilato (PMMA). As escalas de Odom e de Nurick foram utilizadas para avaliar o status funcional dos pacientes antes e após a cirurgia. Radiografias da coluna cervical foram utilizadas para avaliar a artrodese e o alinhamento cervical, pelo menos 2 anos após o procedimento. Resultados: Excelentes e bons resultados (Odom I e II) foram obtidos em $91 \%$ dos casos com radiculopatia e em $69 \%$ dos pacientes com mielopatia. Usando o teste do qui-quadrado de independência ( $1 \%$ de significância), não houve associação entre os resultados excelentes e bons e a presença de artrodese. A presença de alinhamento cervical, ao contrário, correlacionou-se com bons resultados. Dois pacientes faleceram devido a hematoma cervical e migração do enxerto. Conclusão: $\mathrm{O}$ alinhamento cervical correlacionou-se com bons resultados cirúrgicos em nossos pacientes, enquanto que a taxa de artrodese não teve relação com o resultado clínico dos pacientes.
\end{abstract}

PALAVRAS-CHAVE: discectomia, polimetilmetacrilato (PMMA), alinhamento cervical, artrodese.

\footnotetext{
'Department of Neurology and Neurosurgery, Federal University of São Paulo (UNIFESP), São Paulo SP, Brazil; ${ }^{2}$ PhD Student, Department of Neurology, University of Campinas (UNICAMP), Campinas SP, Brazil; ${ }^{3}$ Professor of Neurosurgery, PhD, Federal University of São Paulo (UNIFESP), São Paulo SP, Brazil.
}

Received 1 April 2009, received in final form 13 July 2009. Accepted 4 August 2009.

Dr. Marcelo Luis Mudo - Rua dos Apeninos $930 / 14^{\circ}$ andar - 04104-020 São Paulo SP-Brasil.E-mail: mlmudo@uol.com.br 
Surgical treatment of symptomatic cervical degenerative disease (CDD), with or without myelopathy, is a controversy issue in literature ${ }^{1,2}$. Many options are available, like anterior discectomy, anterior discectomy followed by intervertebral arthrodesis, posterior foraminotomy and, more recently, discectomy followed by arthroplasty ${ }^{3}$.

Each of these techniques has its own variations. Anterior cervical discectomy followed by segmental arthrodesis is one of the most common surgical procedures, with many alternatives to achieve fusion ${ }^{1,4,5}$. Intervertebral interposition of polymethylmetacrylate (PMMA) after anterior discectomy is one of these options, as an alternative to avoid harvesting autologous bone graft. It has low cost; it is safe and efficient, although new materials are used nowadays ${ }^{5,6}$.

We present our experience with the use of PMMA as a disc spacer after cervical discectomy, observing the relationship between arthrodesis and cervical alignment with surgical results in patients with cervical disc disease.

\section{METHOD}

\section{Study information}

This is a retrospective non-controlled study. 48 patients were consecutively submitted to an anterior cervical discectomy followed by intervertebral interposition of PMMA in the segment levels operated, from December 1997 to January 2002 at the Federal University of São Paulo. The ethics committee approval (number 1173/02) was obtained in the reference institution.

\section{Patients selection}

Inclusion criteria: (1) Patients with CDD and symptoms - radiculopathy and/ or cervical myelopathy and (2) Patients with CDD with good clinical and radiological correlation and (3) $\mathrm{Pa}-$ tients with clinical follow-up of at least 2 years.

Exclusion criteria: (1) Presence of encephalic or anterior spinal horn diseases.

Myelopathy diagnoses criteria: At least one of the following signs and symptoms: (1) Sphincter dysfunction (not related with prostate disease); (2) Spasticity on physical examination; (3) Pyramidal signs: Babinski's sign, hyper-reflexia or clonus.

\section{Surgical results evaluation}

Odom scale ${ }^{7}$ : Applied for 46 patients (two were excluded because of dead followed surgical complications), before surgery, on day 1 after the procedure, at six and 24 months after surgery.

Patients with myelopathy were also evaluated with the Nürick Scale ${ }^{8}$, before surgery, on day 1 after the procedure, at 6 and 24 months after surgery.

\section{Radiographic evaluation}

Arthrodesis was evaluated based on cervical X-rays (two view: antero-posterior and lateral), at least 2 years after surgery by an independent radiologist. It was inquired about: presence or absence of arthrodesis (confirmed by an anterior and/ or poste- rior solid bridge bone between two vertebral bodies) $)^{9}$; presence or absence of segmental cervical kyphosis (angulation $>5^{\circ}$ ) on operated segments; presence or absence of vertebral body dislodgement and graft position. Spinal segments were classified in:

(1) With arthrodesis: aligned or misaligned (kyphosis or dislocated).

(2) Without arthrodesis: aligned or misaligned (kyphosis or dislocated).

\section{Surgical techniques}

All patients were submitted to an anterior discectomy of one, two or three levels, using a right side approach. After discectomy of the confirmed levels, a concavity was done in the superior and inferior vertebral end plates to fix the PMMA. The PMMA used was "Surgical Simplex" - radiopaque osseous cement produced by "Howmedica International Ltda. London-England ${ }^{\circledR}$ " (a mixed of polymethymetacrylate metilmetacrilato, copolymer of methymetacrylate styrene and barium sulfate, USP). After partial mixed, when a semi-solid consistency was achieved, the cement was injected into the concavities of the intervertebral space, under constant saline irrigation. To avoiding heat transmission for the neural elements, it was used a gelatin sponge (Gelfoam, Upjohn, Kalamazoo, MI, USA) in the posterior portion of the intervertebral space. The patients were under cervical traction until the complete polymerization. After that, closure was performed, without using drains.

Surgical complications were reported detailed.

\section{RESULTS}

Forty-eight patients were eligible for the included criteria. Unfortunately, two patients with myelopathy died during hospital staying due to surgical complications. They are included on the complications but not in the radiological analysis.

The group was composed by 12 (25\%) women and $36(75 \%)$ men, with age from 20 to 70 years, average of 49.04. Eleven (22.92\%) patients had just radicular symptoms (Nürick Zero), whereas 37 (77.08\%) had symptoms and signs of myelopathy.

Nurick's average was 3.16 (excluding the 11 patients with just radiculopathy). 29 of the 37 (78.37\%) had grade 3 or more in the Nurick's scale - an advanced degree of cervical myelopathy. Symptoms onset were progressive in 34 (70.83\%) patients and abrupt in 14 (29.17\%). Five patients reported a trigger traumatic event before symptoms installation.

Discectomies: 63 discectomies were performed in this group. 35 (72.92\%) patients were submitted to one level discectomy, 11 (22.92\%) in two levels and only two $(4.17 \%)$ were submitted to three levels. The C5-6 was the most frequently treated level - 24 (50\%) patients, followed by the C4-5 level (both together correspond to $73.44 \%$ of all the discectomies). In the 35 patients submit- 


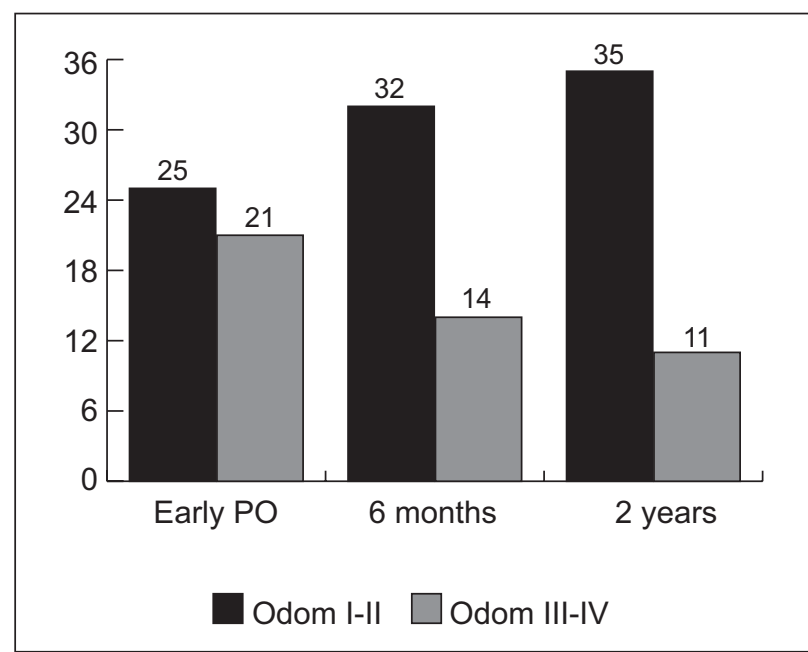

Fig 1. Patients' distribution after surgery according to Odom Scale. Excellent/good results (Odom I and II) and Fair/ poor (Odom III and IV) in the 46 patients submitted to discectomy.

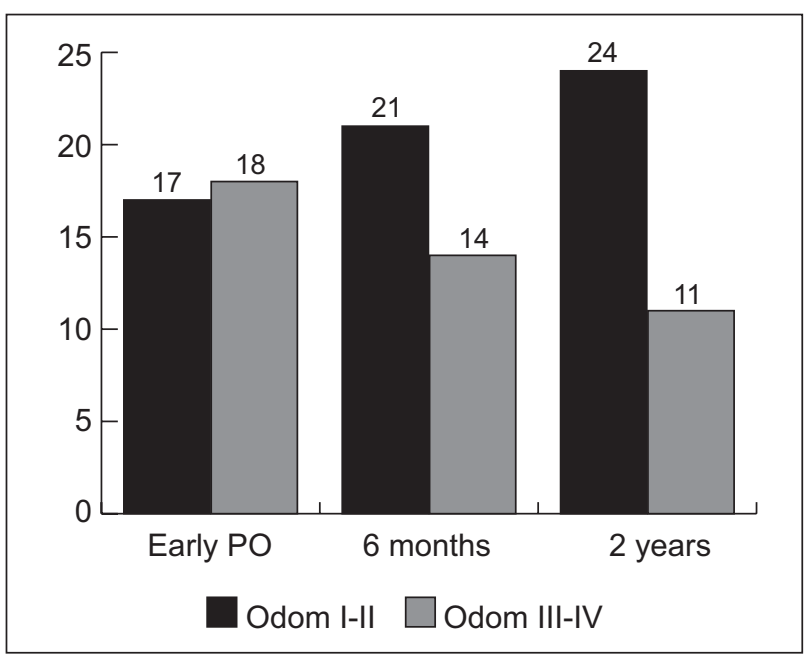

Fig 2. Patients' distribution after surgery according to Odom Scale. Excellent/good (Odom I and II) and Fair/ poor results (Odom III and IV) in the 35 patients with myelopathy submitted to discectomy.

Table 1. Nürick Scale: evaluation in 46 patients with CDD submitted to cervical discectomy with use of PMMA.

\begin{tabular}{ccccc}
\hline Grade & Before surgery patients (\%) & Early PO & 6 months & 2 years \\
\hline Asympt. & 0 & $4(11.42)$ & $6(13.04)$ & $19(41.3)$ \\
Zero & $11(23.91)$ & $7(15.21)$ & $7(15.21)$ & $1(2.17)$ \\
I & $1(2.17)$ & $2(5.71)$ & $8(17.39)$ & $3(6.52)$ \\
II & $5(10.86)$ & $15(42.86)$ & $14(30.43)$ & $14(30.43)$ \\
III & $19(41.30)$ & $13(37.14)$ & $8(17.39)$ & $6(13.04)$ \\
IV & $7(15.21)$ & $3(6.52)$ & $3(6.52)$ & $2(4.34)$ \\
V & $3(6.52)$ & $2(5.71)$ & 0 & $1(2.17)$ \\
Total & 46 & 46 & 46 & 46 \\
& 100 & 100 & 100 & 100 \\
\hline
\end{tabular}

ted to only one level, the C4-5 was the most frequently approached, in 13 cases. The association C4-5 and C5-6 was the most common in two level discectomies, in 6 (12.5\%) patients. Both patients with a 3 level approached were submitted to a $\mathrm{C} 3-\mathrm{C} 4, \mathrm{C} 4-\mathrm{C5}$ e $\mathrm{C} 5-\mathrm{C} 6$ discectomies.

Surgical results: Patients' satisfaction evaluations, according to Odom Scale, for the 46 patients submitted to surgery with PMMA interposition, were shown in Figure 1.

Analyzing just the group of 35 patients with myelopathy (Nurick 1-5) after two years, we observed that (Fig 2): (1) 20 (57.4\%) of the 35 patients with myelopathy had some post-operatory improvement in at least one level in Odom Scale. (2) 10 patients of the 35 with myelopathy symptoms (28.75\%) were asymptomatic (Odom I) and 14 (40\%) had just mild symptoms and normal daily activity (Odom II).

In the radiculopathy group, $10(89.09 \%)$ of the $11 \mathrm{pa}-$ tients were completely asymptomatic or with mild symptoms (Odom I -II).

After 2 years, evaluating the Nürick scale (Table 1), we obtained 19 (41.3\%) asymptomatic patients and the number of patients with severe myelopathy (Nürick III-V) decreased from 29 to 9.

Analyses of the Arthrodesis Rate and Cervical Alignment (Fig 3): (1) 18 (39.13\%) patients had a solid arthrodesis with an aligned cervical spine; (2) Six (13.04\%) patients had arthrodesis but with cervical kyphosis; (3) 13 (28.26\%) did not have arthrodesis but they maintained cervical alignment; (4) Six (13.04\%) patients did not have signs of arthrodesis and have a misaligned cervical spine; (5) two (4.35\%) patients have graft migration into the vertebral body without arthrodesis and cervical rectification; 6) one (2.17\%) patient had a posterior graft migration.

Applying the chi square test of independence to test the association between the variables using $1 \%$ of significance ( $99 \%$ of probability), the presence of arthrodesis did not have correlation with excellent and good surgical results. However, cervical alignment had good correlation with excellent and good results. 


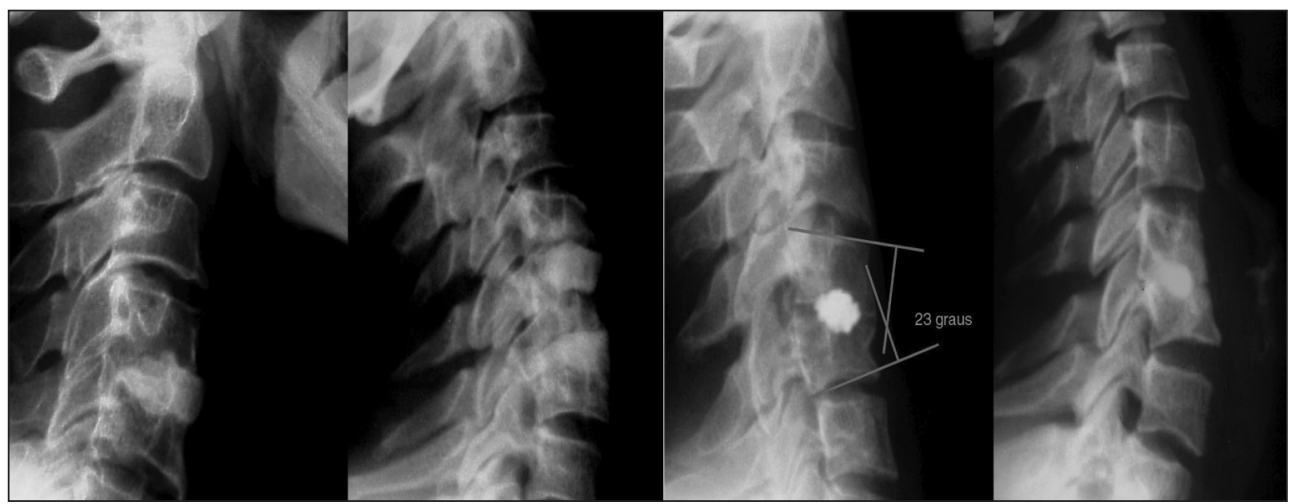

Fig 3. Cervical spine X-ray - lateral view: [A] aligned cervical spine with good arthrodesis; [B] aligned cervical spine without arthrodesis; [C] misaligned cervical spine without arthrodesis; [D] misaligned cervical spine with arthrodesis.

Table 2. Relationship between surgical results and arthrodesis in 46 patients submitted to cervical discectomy with PMMA.

\begin{tabular}{lccc}
\hline Results & With arthrodesis & Without arthrodesis & Total \\
\hline Excellent-good & $17(36.95)$ & $17(36.95)$ & $34(73.91)$ \\
Fair-poor & $7(15.21)$ & $5(10.87)$ & $12(26.09)$ \\
Total & $24(52.17)$ & $22(47.82)$ & $46(100)$ \\
\hline
\end{tabular}

Table 3. Relationship between surgical results and segmental cervical alignment in 46 patients submitted to cervical discectomy with PMMA.

\begin{tabular}{lccc}
\hline Results & Cervical spine-aligned & Cervical spine-misaligned & Total \\
\hline Excellent-good & $29(63.04)$ & $5(10.87)$ & $34(73.91)$ \\
Fair-poor & $2(4.35)$ & $10(21.74)$ & $12(26.09)$ \\
Total & $31(67.39)$ & $15(32.61)$ & $46(100)$ \\
\hline
\end{tabular}

In Table 2 and 3, we present the relationship between surgical results versus arthrodesis and surgical results versus vertebral alignment.

Complications: There were no complications in the radiculopathy group. In the myelopathy group, a high level of complications was obtained, described as following: four cases of transitory dysphonia, one cervical hematoma, one superficial infection and one cerebrospinal fluid leak. There were also three grafts dislodgement and one case of radiculopathy. One of the two obits was due to a cervical hematoma in a three level discectomy with respiratory failure and prolonged mechanical ventilation, leading to sepse and obit. The other one was secondary to a rethrolisthesis of C3-4 with cord compression, prolonged mechanical ventilation and sepse in a two level discectomy.

\section{DISCUSSION}

Patients submitted to simple discectomy generally have a high level of post operative cervical pain ${ }^{10}$ probably due to cervical instability. Grafting use can decrease post operatory cervical pain and increase spine stabili- ty ${ }^{11}$. In our studied group, we had only $3(6.52 \%)$ patients with cervical pain after surgery. Morbidity associated to autologous graft is described in many papers, like graft collapsing, iliac crest pain or hematoma, dysphagia, deformities, dislodgment ${ }^{12}$, leading to new alternatives for autologous graft.

There was any data, as far as we know, comparing specifically the cervical alignment after surgery with clinical results or post operative cervical pain ${ }^{13}$. However, Katsuura correlated misalignment and cervical kyphosis with and increase incidence of adjacent level intervertebral degeneration ${ }^{14}$. There was no evidence that arthrodesis in kyphosis or in anatomical position change patient outcomes in long-term follow-up 15 .

Although a low arthrodesis' rate was obtained by our patients after using PMMA, clinical outcome was not different between the group with and without arthrodesis.

Reviewing English literature, we can realize a tendency to preclude the use of PMMA because of its lower arthrodesis rates ${ }^{15-18}$ and a high rate of complications ${ }^{19-21}$.

However, Germany literature represents an opposite 
point of view: they affirm that PMMA is safe and efficient, sometimes safer than the autologous bone, with fewer rates of fracture and extrusion ${ }^{5,22,23}$. As an example, Schröder et al., performed a prospective study with 107 patients with cervical radiculopathy submitted to anterior cervical discectomy, comparing titanium cages with PMMA. Both groups had similar clinical results, but the cage group had a greater arthrodesis rate $(87 \%$ of fusion versus $66 \%$ in the PMMA group, $p=0,011)$. Good and satisfactory results were obtained (Odom Scale) in 25 of the 54 patients of the cage group versus 27 of 53 in the PMMA group, without significant statistic difference.

In our study, results of cervical radiculopathy using PMMA showed good clinical outcome - $91 \%$ of our patients had an excellent or a good outcome after at 2 years of follow-up, without any complication. Although modest, the results are encouraging.

Myelopathic patients in our study had an advanced disease in more than $80 \%$ of the cases (Nurick greater than 2). When we analyzed the surgical results, 24 of 35 patients had excellent or good results. Moreover, some patients with Nürick 3 to 5 reported extremely satisfaction with surgical results despite a small changed of one or two points in the scale. However, fatal complications (two cases $-5.7 \%$ ) was very high in this casuistic, possible precluding the use of PMMA.

Extrusion and dislodgement rates, in our opinion, are strongly related to surgical technique used. Meticulous end plate preparation, with concavities in the vertebral bodies, can reduce these complications to the levels of germane literature.

Excellent and good results in the radiculopathy (91\%) and myelopathy $(69 \%)$ were similar to the literature ${ }^{1,23,24}$.

As we showed in the results, arthrodesis rate was just achieved in $52 \%$ of our cases. A similar low rate of arthrodesis was found in patients without clinical improvement $(42 \%)$ and with good clinical results $(50 \%)$, suggesting that arthrodesis was not responsible for treatment success. However, the presence of cervical kyphosis in patients without clinical improvement (83.3\%) was significantly greater than in the group with good results (14.71\%), pointed that cervical alignment was more important to surgical outcome than the arthrodesis rate in treatment of CDD in our group of patients.

Although we do not use PMMA anymore, since new modern techniques for anterior cervical discectomy are available, we think that this paper is unique in emphasize the importance of a good cervical alignment after CDD surgery to achieve a good clinical outcome.

\section{REFERENCES}

1. Bärlocher CB, Barth A, Krauss JK, Binggeli R, Seiler RW. Comparative evaluation of microdiscectomy only, autograft fusion, polymeth- ylmethacrylate interposition, and threaded titanium cage fusion for treatment of single-level cervical disc disease: a prospective randomized study in 125 patients Neurosurg Focus 2002;12:1-5.

2. Hauerberg J, Kosteljanetz M, Bøge-Rasmussen T, et al. Anterior cervical discectomy with or without fusion with ray titanium cage: a prospective randomized clinical study. Spine 2008;33:458-464.

3. Sasso RC, Smucker JD, Hacker RJ, Heller JG. Artificial disc versus fusion: a prospective, randomized study with 2-year follow-up on 99 patients. Spine 2007;32:2933-2940.

4. Samii M, Völkening D, Sephernia A. Surgical treatment of myeloradiculopathy in cervical spondilosis: a report of 348 operations. Neurosurg Rev 1989;12:285-290.

5. Schröder J, Grosse-Dresselhaus F, Schul C, Wassmann H. PMMA versus titanium cage after anterior cervical discectomy: a prospective randomized trial. Zentralbl Neurochir 2007;68:2-7.

6. Lesoin F, Pellerin P, Thomas CE, et al. Acrylic reconstruction of an arthritic cervical spine using the transcervical-transclival approach Surg Neurol 1984;22:329-334.

7. Odom GL, Finney W. Cervical disc lesions. JAMA 1958;166:23-28

8. Nurick $\mathrm{S}$. The natural history and the results of surgical treatment of the spinal cord disorder associated with cervical spondylosis. Brain 1972;92:101-108

9. Zdeblick TA, Ducker TB. The use of freeze-dried allograft bone for anterior cervical fusions. Spine 1991;16:726-729.

10. van den Bent MJ, Oosting J, Wouda EJ, Van Acker EH, Ansink BJ, Braakman R. Anterior cervical discectomy with or without fusion with acrylate. A randomized trial. Spine 1996;21:834-839.

11. Wang J L, Panjabi MM, Isomi T. The role of bone graft force in stabilizing the multilevel anterior cervical spine plate system. Spine 2000;25:1649-1654.

12. Profeta G, De Falco R, Ianniciello G, Profeta L, Cigliano A, Raja AI. Preliminary experience with anterior cervical microdiscectomy and interbody titanium cage fusion (Novus CT-Ti) in patients with cervical disc disease. Surg Neurol 2000;53:417-426.

13. Gaetani P, Tancioni F, Spanu G, Rodriguez Y, Baena R. Anterior cervical discectomy: an analysis on clinical long-term results in 153 cases J Neurosurg Sci 1995;39:211-218.

14. Katsuura AS, Hukuda Y, Saruhashi KM. Kyphotic malalignment after anterior cervical fusion is one of the factors promoting the degenerative process in adjacent intervertebral levels. Eur Spine J 2001;10:320-324.

15. Wigfield CC, Nelson RJ. Nonautologous interbody fusion materials in cervical spine surgery. how strong is the evidence to justify their use? Spine 2001;26:687-694.

16. Panjabi MM, Goel VK, Clark CR, Keggi KJ, Southwick WO. Biomechanical study of cervical spine stabilization with methylmethacrylate. Spine 1985;10:198-203.

17. Whitehill R, Barry JC. The evolution of stability in cervical spine constructs using either autogenous bone or methylmethacrylate cement: a follow-up report on a canine in vivo model. Spine 1985;10:32-41.

18. Whitehill R, Stowers SF, Fechner RE, et al. Posterior cervical fusions using cerclage wires, methylmethacrylate cement and autogenous bone graft: an experimental study of a canine model. Spine 1987;12:12-22.

19. Jordan SE, Bremer AM, Nguyen TQ. An unusual late complication of acrylic spinal fusion: case report. Neurosurgery 1983;13:441-442.

20. Halligan M, Hubschmann OR. Short-term and long-term failures of anterior polymethylmethacrylate construct with esophageal perforation. Spine 1993;18:759-761.

21. Thomas JP, Finch R. Esophageal erosion. A complication of acrylic fixation in anterior cervical fusion. Spine 1991;16:1238-1240.

22. Grote W, Kalff R, Roosen K. Die operative Behandlung zervikaler Bandscheibenvorfälle. Zentralbl Neurochir 1991;52:101-108.

23. Schroder J, Wassmann H. Polymethylmethacrylate (PMMA) in anterior cervical spine surgery - current situation in Germany. Zentralbl Neurochir 2001;62:33-36.

24. Chen JF, Wu CT, Lee SC, Lee ST. Use of a polymethylmethacrylate cervical cage in the treatment of single-level cervical disc disease. J Neurosurg Spine 2005;3:24-28. 